Article

\title{
Extracellular Heme Proteins Influence Bovine Myosatellite Cell Proliferation and the Color of Cell-Based Meat
}

\author{
Robin Simsa ${ }^{1,2,3}{ }^{\circledR}$, John Yuen ${ }^{1}{ }^{\circledR}$, Andrew Stout ${ }^{1}$, Natalie Rubio ${ }^{1}{ }^{\circledR}$, Per Fogelstrand ${ }^{3}$ and \\ David L. Kaplan 1,* \\ 1 Department of Biomedical Engineering, Tufts University, Medford, MA 02155, USA; \\ robin.simsa@verigraft.com (R.S.); John.Yuen_Jr@tufts.edu (J.Y.); Andrew.Stout@tufts.edu (A.S.); \\ Natalie.Rubio@tufts.edu (N.R.) \\ 2 VERIGRAFT AB, 41346 Gothenburg, Sweden \\ 3 Wallenberg Laboratory, University of Gothenburg, 41345 Gothenburg, Sweden; Per.Fogelstrand@wlab.gu.se \\ * Correspondence: david.kaplan@tufts.edu; Tel.: +617-627-3251
}

Received: 10 October 2019; Accepted: 18 October 2019; Published: 21 October 2019

check for updates

\begin{abstract}
Skeletal muscle-tissue engineering can be applied to produce cell-based meat for human consumption, but growth parameters need to be optimized for efficient production and similarity to traditional meat. The addition of heme proteins to plant-based meat alternatives was recently shown to increase meat-like flavor and natural color. To evaluate whether heme proteins also have a positive effect on cell-based meat production, bovine muscle satellite cells (BSCs) were grown in the presence of hemoglobin $(\mathrm{Hb})$ or myoglobin $(\mathrm{Mb})$ for up to nine days in a fibrin hydrogel along 3D-printed anchor-point constructs to generate bioartificial muscles (BAMs). The influence of heme proteins on cell proliferation, tissue development, and tissue color was analyzed. We found that the proliferation and metabolic activity of BSCs was significantly increased when $\mathrm{Mb}$ was added, while $\mathrm{Hb}$ had no, or a slightly negative, effect. $\mathrm{Hb}$ and, in particular, $\mathrm{Mb}$ application led to a very similar color of BAMs compared to cooked beef, which was not noticeable in groups without added heme proteins. Taken together, these results indicate a potential benefit of adding $\mathrm{Mb}$ to cell culture media for increased proliferation and adding $\mathrm{Mb}$ or $\mathrm{Hb}$ for the coloration of cell-based meat.
\end{abstract}

Keywords: cell-based meat; cultured meat; skeletal muscle tissue engineering; muscle constructs; bioartificial muscle; heme proteins; hemoglobin; myoglobin; meat color; tissue color; bovine myosatellite cells; cellular agriculture

\section{Introduction}

Muscle tissue engineering in vitro may provide new treatments for skeletal muscle diseases such as muscular dystrophies or trauma. Another application of muscle tissue engineering is the generation of meat, derived from livestock animal cells, for human consumption, here referred to as cell-based meat (other common names include "cultured meat", "in vitro meat", or "cellular agriculture"). The rationale for developing cell-based meat is the potential to decrease resource intensity and increase environmental sustainability of meat production [1] compared to current industrial animal farming, which is associated with issues of greenhouse gas emission, land usage [2], deforestation [3], biodiversity [4], antibiotic resistance [5], and animal welfare. The ability to grow meat in defined bioreactor conditions also potentially allows a decrease in the use of steroid hormones [6] and antibiotics [7], while increasing the content of health-related proteins and vitamins by defined nutrient composition of cell culture media. Currently, the generation of muscle tissue in large quantities is not cost-efficient, since knowledge about 
muscle tissue engineering was generated mainly related to medical applications. Therefore, more basic research regarding optimization and production of muscle tissue for food products is necessary.

The main component of meat is skeletal muscle cells, which, therefore, is a logical starting cell type for cell-based meat production. However, differentiated skeletal muscle cells cannot be expanded in vitro, as they lose their ability to proliferate in normal conditions $[8,9]$. In contrast, myosatellite cells, which are muscle progenitor cells, have a greater capacity to proliferate and differentiate [10]. Myosatellite cells can be harvested from non-lethal biopsies and then grown in 3D to form bioartificial muscle (BAM) constructs by growth in hydrogels, on synthetic or natural scaffolds or on native decellularized extracellular matrix [11-13]. Differentiation of myosatellite cells into adult muscle tissue can be initiated by changing the media conditions, topographical cues, electrical or mechanical stimuli, or other modes [14]. Three-dimensional growth of skeletal muscle in hydrogels along agarose pillars was the basis of the first demonstration of a cell-based meat prototype $[15,16]$. Growth of skeletal muscle tissue requires the presence of functional proteins, which are commonly added with fetal bovine serum or by the addition of specific growth factors (e.g., fibroblast growth factor (FGF) or vascular endothelial growth factor (VEGF)) [17]. Other functional proteins which could have an important role in cell-based meat development are heme proteins, such as myoglobin $(\mathrm{Mb})$ or hemoglobin $(\mathrm{Hb})$.

Heme proteins contain a prosthetic group with a bound iron atom and fulfill functions such as oxygen binding and transport to mitochondria, oxidative phosphorylation, and intracellular catalysis $[18,19] . \mathrm{Hb}$ is primarily found in red blood cells, while $\mathrm{Mb}$ is found in native skeletal and cardiac muscle tissue [20]. The content and redox form of $\mathrm{Mb}$ is the main contributor to the color of meat [21] and is associated with the typical bloody, metallic taste of meat [22]. These attributes are of great interest for cell-based meat development, as both taste and color of meat are crucial for consumer acceptance [23]. Skeletal muscle cells only produce limited amounts of $\mathrm{Mb}$ in vitro when proliferating, and $\mathrm{Mb}$ content in vitro is lower compared to in vivo muscle tissue [24]. Therefore, increasing the content of heme proteins during muscle tissue formation may lead to a more meat-like composition and appearance. Heme proteins such as $\mathrm{Hb}$ are already widely used in meat products, as natural color enhancers, binders, or fat replacers [25]. Also, the addition of heme proteins to food products can help to reduce iron deficiency, which affects up to $20 \%$ of the world population [26].

Increasing heme protein expression in skeletal muscle cell culture may be achieved by adaption of growth conditions, such as hypoxic incubation or addition of certain supplements, but raises issues in terms of food regulatory aspects, production feasibility and/or cell viability. For example, muscle cells are one of the few cell types that proliferate well in hypoxic conditions [27], limiting coculture systems. Another option of increasing the heme protein content is the addition of extracellular heme proteins in growth media directly during cell proliferation and differentiation, which can have a positive effect on cell metabolism $[19,28,29]$. Recently, the commercially available meat substitute "Impossible Burger" has incorporated heme proteins originating from soy (leghemoglobin) into a soy-based alternative for ground beef, which led to a more meat-like taste compared to a control group without added heme [30]. These results showed the potential of heme proteins to be used in meat alternatives to recreate natural meat taste and flavor. However, the incorporation of heme proteins in cell culture for cell-based meat production has not yet been investigated.

The aim of this study was to investigate the effects of direct additions of the heme proteins $\mathrm{Hb}$ and $\mathrm{Mb}$ on skeletal muscle cell proliferation, differentiation, coloration, biochemical activity, and viability. Experiments were performed on primary isolated bovine satellite cells (BSCs). For tissue formation, cells were cultured in a fibrin hydrogel and differentiated along 3D printed anchor point constructs. Color measurements and heme content were compared to commercially available ground beef. 


\section{Materials and Methods}

\subsection{Bovine Satellite Cell Isolation and Cell Culture}

Primary bovine satellite cells were isolated from the semitendinosus of a 60-day-old male Charolaise $x$ Simmental beef cow raised at the Tufts Cummings School of Veterinary Medicine. Briefly, a small excision $\left(\sim 0.5 \mathrm{~cm}^{3}\right)$ was taken according to methods approved by the Tufts University Institutional Animal Care and Use Committee (IACUC Protocol \#G2018-36), placed in dulbecco's modified eagle medium (DMEM) + Glutamax (ThermoFisher, Pittsburg, PA, USA) with 1\% antibiotic-antimycotic, and transported to the lab on ice, where fat and connective tissue were removed before the remaining muscle was minced into a thick paste. Minced tissue was divided into $50 \mathrm{~mL}$ tubes with $20 \mathrm{~mL}$ DMEM Glutamax and centrifuged at $200 \times g$ for $5 \mathrm{~min}$. The media was aspirated, and the tissue was resuspended in $10 \mathrm{~mL}$ DMEM + Glutamax with $0.2 \%$ collagenase II (Worthington Biochemical, Lakewood, NJ, USA; $275 \mathrm{U} / \mathrm{mg}$ ). This digestion solution was incubated for $45 \mathrm{~min}$ at $37{ }^{\circ} \mathrm{C}$, with micropipette triturations performed every $15 \mathrm{~min}$. Then, the solution was triturated using an 18-gauge blunt-tipped needle until it passed through the needle easily, incubated at $37^{\circ} \mathrm{C}$ for another 15 min, and again triturated several times with an 18-gauge needle. Next, $20 \mathrm{~mL}$ of growth media comprised of DMEM + Glutamax supplemented with 20\% FBS, $1 \mathrm{ng} / \mathrm{mL}$ human FGF-basic (100-18B, PeproTech, Rocky Hill, NJ, USA), and 1\% Primocin (Invivogen, San Diego, CA, USA) was added to both tubes to halt digestion. Digests were filtered through $70 \mu \mathrm{m}$ and $40 \mu \mathrm{m}$ cell strainers, centrifuged at $200 \mathrm{~g}$ for $5 \mathrm{~min}$, and resuspended in growth media. Cells were then counted on a hemocytometer, plated at a density of 100,000 cells $/ \mathrm{cm}^{2}$ onto uncoated T75 tissue-culture flasks, and incubated in a $37^{\circ} \mathrm{C}$ with $5 \% \mathrm{CO}_{2}$. After $24 \mathrm{~h}$, the media was collected from flasks to separate slowly adherent satellite cells from quickly adherent fibroblasts and transferred directly to new tissue-culture flasks coated with $1 \mu \mathrm{g} / \mathrm{cm}^{2}$ mouse laminin (Millipore, Burlington, MA, USA). Flasks were left untouched for three days, at which point growth media was changed, and cells were cultured using standard practices on tissue-culture plastic coated with iMatrix recombinant laminin-511 (NC1547124, iMatrix-511, Fisher, Waltham, MA, USA). After two weeks of culture, puromycin in growth media was replaced with $1 \%$ antibiotic-antimycotic. For differentiation, media comprised DMEM + GlutaMax enriched with 2\% FBS and 1\% Antibiotic-Antimycotic solution.

\subsection{Proliferation Assay}

A proliferation assay was performed using CyQuant Reagent (ThermoFisher), following the supplier's instructions. Briefly, BSCs were seeded in a 96-well plate at a density of 500 cells/well. Cell culture media consisted of either standard proliferation media or proliferation media with added hemoglobin from bovine blood (Sigma, St Louis, MO, USA) or myoglobin from equine skeletal muscle (Sigma) in concentrations of 1,3 , or $5 \mathrm{mg} / \mathrm{mL}$. Both proteins were provided by the supplier in the oxidized met redox form (metmyoglobin or methemoglobin). Four plates were prepared with 6 replicates per group $(n=6)$ and single plates were recovered after $1,3,5$, and 7 days of incubation by aspirating the media and storage at $-80^{\circ} \mathrm{C} .100 \mu \mathrm{L}$ media was aspirated and replaced by fresh media after 4 days. When all plates were recovered, CyQuant working solution was prepared by diluting the supplied lysis reagent 1:20 in sterile $\mathrm{H}_{2} \mathrm{O}$, followed by the addition of the dye reagent to a dilution of 1:400. Plates were thawed at room temperature, and $200 \mu \mathrm{L}$ of CyQuant working solution was added to each well. Fluorescence was measured at an excitation of $480 \mathrm{~nm}$ and emission of $520 \mathrm{~nm}$ with a spectrophotometer (Synergy H1, Biotek, Winooski, VT, USA). Cell number was calculated with a standard curve of cells seeded at a known density.

\subsection{D BAM Formation}

BSC differentiation was based on anchor point attachment in a fibrin hydrogel. To allow elongation and differentiation of BSCs along 2 anchor points, an anchor point construct fitting into individual wells of a 24-well plate in different confirmations was designed with SolidWorks and 3D printed on a 
desktop 3D printer (3DWOX 201, Sindoh, South Korea) with standard polylactide (PLA) filament (S1 File). One day prior to BSC seeding, individual wells of 24-well plates were treated at RT with $1 \mathrm{~mL}$ of 5\% Pluronic F-127 (P2443, Sigma) to decrease cell attachment to the well surfaces. After $30 \mathrm{~min}$, the liquid was aspirated and the plate was kept with open lid in the flow hood for $1-2 \mathrm{~h}$ to ensure complete evaporation. Anchor point constructs were sterilized with $70 \%$ ethanol and stored together with the 24-well plate overnight under UV light.

For BAM formation, BSCs at a density of $3.5 \times 10^{6}$ cells/well were combined with $20 \mathrm{mM} \mathrm{CaCl}_{2}$ in proliferation media. For groups with heme protein, proliferation media also contained $\mathrm{Hb}$ or $\mathrm{Mb}$ at a concentration of $3 \mathrm{mg} / \mathrm{mL}$. Cell mixture was added to individual wells with pre-added thrombin from bovine plasma (Sigma) with a total enzyme activity of $0.6 \mathrm{U}$. Finally, bovine concentrated plasma fibrinogen stock (341573, EMD Millipore, Bedford, MA, USA) diluted in $\mathrm{H}_{2} \mathrm{O}$ was added to make up a final concentration of $3 \mathrm{mg} / \mathrm{mL}$, and the solution was mixed quickly by pipetting up and down multiple times. All reagents were sterile-filtered prior to use. The total volume of the cell-reagent mix was $800 \mu \mathrm{L}$. Furthermore, the fibrinolytic inhibitor aminocaproic acid (ACA) (Sigma), at a concentration of $1 \mathrm{mg} / \mathrm{mL}$, was added to BSC-Fibroin mix, as well as to media, to prevent rapid hydrogel degradation. To observe muscle tissue formation without fibrinolysis inhibitor, one batch was incubated without ACA. Plates were incubated for at least $30 \mathrm{~min}$, at $37^{\circ} \mathrm{C}$, to initiate hydrogel polymerization. Then, $1.2 \mathrm{~mL}$ of respective proliferation media containing either no or $3 \mathrm{mg} / \mathrm{mL}$ of heme proteins was added to each well, and incubation continued at $37^{\circ} \mathrm{C}$. After 1 day, media was aspirated and replaced with differentiation media. Every 3 days, media was replaced with fresh media, containing the respective heme proteins. After 9 days, BAMs were removed with forceps from anchor-point construct for further analysis. As a control for hydrogel compaction, gel without added cells was used. Prior to tissue harvesting, thickness and width were measured with a digital caliper while still on the construct. The length was equal to spacing between the 3D constructs' anchor points (13.14 mm end-to-end). Weight was measured with a standard lab balance. For further analysis, groups were compared against commercially available ground beef $(80 \%$ lean, $20 \%$ fat) purchased from a local supermarket.

\subsection{Time-Lapse Imaging}

Initial BAM formation was visualized with a BZ-X710 fluorescent microscope (Keyence, Japan). Then, $3.5 \times 10^{6} \mathrm{BSC}$ in a fibrin hydrogel were prepared, as described above, and incubated for $30 \mathrm{~min}$ at $37^{\circ} \mathrm{C}$, to induce gelation. Media was then added, and the plate was transferred to the microscope in a thermo-, and gas-stable chamber at $37^{\circ} \mathrm{C}$ and $\mathrm{CO}_{2}$ of $5 \%$. Images of different regions of the gel were taken with z-Stack every $15 \mathrm{~min}$ for $12 \mathrm{~h}$. Time-lapse video was prepared with KEYANCE BZ-X Analyzer software at 2 frames per second.

\subsection{Biochemical Analysis}

Nitric oxide release of BAM was quantified with a commercially available kit (Total Nitric Oxide and Nitrate/Nitrite Parameter Assay Kit, R\&D Systems, Minneapolis, MN, USA), by following the supplier's instructions. Briefly, BAMs were grown in fibrin hydrogel with differentiation media, and media recovered after $72 \mathrm{~h}$ of incubation $(n=5)$. The media was centrifuged for $3 \times 10 \mathrm{~min}$ at 13,400 $\mathrm{rpm}$ to remove particles, and 50 of $\mu \mathrm{L}$ supernatant (diluted 1:5) was added to a 96-microwell plate. Indirect measurement of nitric oxide was performed by measuring the level of nitric oxide metabolites nitrate and nitrite assay with Griess reagent, and absorbance measured at $540 \mathrm{~nm}$. Concentration was calculated from a nitrite and nitrate standard. Soluble Glycosaminoglycan (GAG) released by the cells was measured with a GAG Kit (Chondrex, Redmond, WA, USA). Briefly, media was removed from BAMs, following $72 \mathrm{~h}$ of incubation, and added to a 96-well plate in duplicates $(n=6)$ with different dilutions. Samples were then either incubated in $100 \mu \mathrm{L}$ of Dye Reagent or $100 \mu \mathrm{L}$ of PBS as a control, and absorbance was measured at $525 \mathrm{~nm}$. Concentration was calculated from a known standard. 


\subsection{DNA Quantification}

DNA from 7-15 mg of wet tissue was extracted using the DNeasy Blood and Tissue Kit (Qiagen, Hilden, Germany), following the manufacturer's instructions. Briefly, BAM samples $(n=4)$ were incubated at $55^{\circ} \mathrm{C}$ with proteinase $\mathrm{K}$ solution, until the tissue was completely digested. DNA was extracted with spin columns and measured with a Qubit 3.0 Fluorometer (ThermoFisher). The total amount of DNA was calculated from a known DNA standard.

\subsection{Immunohistochemistry}

To verify the identity and myogenicity of isolated bovine satellite cells, they were cultured in 2D and stained for Pax7 during proliferation, or for Troponin T, following one week of differentiation. To evaluate cell development in fibrin hydrogels, BAMs were cultured for 9 days, and stained for Troponin T. For all immunofluorescent staining, the same protocol was used. Briefly, cells or BAMs were fixed at room temperature for 30 min using $4 \%$ paraformaldehyde, washed in PBS $3 \times$, and stored in PBS at $4{ }^{\circ} \mathrm{C}$ before staining. For staining, cells were permeabilized for $15 \mathrm{~min}$ using $0.5 \%$ Triton-X (Sigma, St Louis, MO, USA) in PBS, blocked for $45 \mathrm{~min}$, using $5 \%$ goat serum (Gibco) in PBS with $0.05 \%$ sodium azide (Sigma), and washed 3x with PBS containing 0.1\% Tween-20 (Sigma). Primary Pax7 antibodies (Thermo Fisher, \#PA5-68506) were diluted 1:100 in blocking solution containing 1:100 Phalloidin 594 (Thermo Fisher, Pittsburg, PA, USA; \#A12381) and added to 2D proliferating cells. Primary Troponin $\mathrm{T}$ antibodies (developmental studies hybridoma bank, CT3) were diluted to $4 \mu \mathrm{g} / \mathrm{mL}$ in blocking solution containing 1:100 Phalloidin 594 (Thermo Fisher, \#A12381) and added to 2D differentiated cells or BAMs. Primary antibodies were incubated overnight at $4{ }^{\circ} \mathrm{C}$. The following day, cells or BAMs were washed $3 \times$ with PBS + Tween-20. For 2D, secondary antibodies for Pax7 (Invitrogen, Carlsbad, CA, USA; goat-anti-rabbit AlexaFluor-488, \#A-11008, 1:500) and Troponin T (Thermo Fisher Scientific goat-anti-mouse AlexaFluor-488, \#A-11001, 1:1000) were diluted in blocking solution and added to cells for $1 \mathrm{~h}$ at room temperature. Cells were washed $3 \times$ with PBS + Tween-20 and mounted with Fluoroshield mounting medium with DAPI (Abcam, Cambridge, UK) before imaging. For BAMs, secondary antibodies for Troponin $\mathrm{T}$ were diluted in blocking solution containing DAPI (Thermo Fisher, \#62248, 1:1000) and added to constructs for $1 \mathrm{~h}$ at room temperature. Constructs were washed $3 \times$ and stored in PBS + Tween-20 for imaging.

\subsection{Live-Dead Staining and Alignment Quantification}

After 8 days of incubation, BAMs were incubated with differentiation media containing $2 \mu \mathrm{M}$ calcein AM and $4 \mu \mathrm{M}$ of ethidium homodimer (L3224, ThermoFisher) for $30 \mathrm{~min}$ at $37^{\circ} \mathrm{C}$. Live-dead stained samples $(n=3)$ were then Z-stack and/or XY-stitch imaged, using the $488 \mathrm{~nm}$ and $594 \mathrm{~nm}$ filters on a BZ-X700 fluorescent microscope (Keyence, Japan). The alignment of muscle cells was quantified from calcein AM images by ImageJ with the Fiji plugin. Briefly, images were transformed into 16-bit type and analyzed individually with the "Directionality" tool. The analysis was set to Fourier components, 90 bins and $-90^{\circ}$ to $+90^{\circ}$. The obtained histogram was normalized to the main axis, e.g., the orientation angle with most alignment. Normalized data were used for calculation of aligned structures within $10^{\circ}$ and $-10^{\circ}$ of the main axis.

\subsection{Scanning Electron Microscopy (SEM)}

BAMs were dehydrated for $10 \mathrm{~min}$ at a time in $35 \%, 60 \%, 80 \%, 90 \%, 95 \%$, and $100 \%$ ethanol, after which they were transferred into hexamethyldisilazane (Sigma) for $10 \mathrm{~min}$. Hexamethyldisilazane was then aspirated and samples were left to air-dry in a fume hood. Prior to SEM imaging, samples $(n=5)$ were sputter-coated with gold for 120 s, using a SC7620 sputter coater (Quorum Technologies, East Sussex, UK). Imaging was performed on a Zeiss EVO-10MA scanning electron microscope (Zeiss, Jena, Germany). 


\subsection{Color Image Analysis}

BAMs were placed, while still on the 3D-printed anchor construct, on a petri dish with a white background, within a flow hood, and images were taken with a digital camera (Canon DS126311), with 2 fluorescent lamps as illumination. Camera settings were ISO 200 and 1/20 s exposure. Images of beef samples were also taken in the same conditions. Images were then analyzed on ImageJ (v1.51, $\mathrm{NIH}$ ) for RGB colors, by measuring several areas per sample and calculating the mean. RGB colors were furthermore converted into $L^{*} a^{*} b^{*}$ colors, where $L^{*}$ shows lightness, $a^{*}$ red/green spectra, and $b^{*}$ blue/yellow spectra of the sample. Overall changes of color compared to either fresh beef or cooked beef was expressed as delta $\mathrm{E}(\Delta \mathrm{E})$, following the CIE76 formula:

$$
\Delta E=\sqrt{\left(L^{*}{ }_{2}-L^{*}{ }_{1}\right)^{2}+\left(a^{*}{ }_{2}-a^{*}{ }_{1}\right)^{2}+\left(b^{*}{ }_{2}-b^{*}\right)^{2}},
$$

where $L_{2}^{*}, a^{*}{ }_{2}$, and $b^{*}{ }_{2}$ express the values of the respective BAM sample, while $L^{*}{ }_{1}, a^{*}$, and $b^{*}$ express the average values of either fresh or cooked beef. $\Delta \mathrm{E}$ expresses the relative color difference between 2 samples. While $\Delta \mathrm{E}=0$ shows identical colors, low values indicate high similarity, and high values indicate low similarity between two colors.

\subsection{Cooking of Beef Samples}

To compare color of BAMs with cooked beef, beef samples were cooked on a hot plate in a metal mold. First, beef samples were cut into small pieces, similar to the size of the BAMs. Prior to cooking, the weight of samples was measured and the hot plate heated to $145^{\circ} \mathrm{C}$. A stainless steel base mold (Thermo Fisher) was moistened with a small volume of olive oil and put in the center of the hot plate. After several minutes, a single sample was added onto the metal mold with forceps and heated for $30 \mathrm{~s}$. Then, the sample was turned to the other side, and heating continued for $30 \mathrm{~s}$. Finally, the sample was recovered and weighed after cooking. Then, images of the sample were taken for color analysis, as described above.

\subsection{Total Pigment Extraction}

Total pigment extraction was performed following previously published protocols [31,32]. Briefly, 20-60 mg samples of BAM and beef were added to a $0.1 \mathrm{M}$ sodium phosphate buffer with a total volume of $10 \times$ the tissue weight and homogenized (Polytron PT 10-35, FisherSci, Hampton, NH, USA). Pigments were extracted for at least $1 \mathrm{~h}$ at RT, after which homogenate was centrifuged $3 \times 15 \mathrm{~min}$ at $13,000 \mathrm{rpm}$, and the supernatant was taken for absorbance spectra measurement. Total pigments were calculated from a prepared standard of known concentration of $\mathrm{Hb}$ or $\mathrm{Mb}$. BSCs, BSCs $+\mathrm{Mb}$, and ground beef showed maximum absorbance at $409 \mathrm{~nm}$ (Metmyoglobin), BSCs + Hb showed maximum absorbance at $406 \mathrm{~nm}$ (Methemoglobin). Therefore, the concentration of different groups was calculated with the standard curve of the respective protein.

\subsection{Statistical Analysis}

GraphPad Prism 8 was used for all statistical analyses. For comparisons of multiple groups for only one parameter, one-way ANOVA and Tukey's multiple comparison tests were applied. Significance is indicated in bar graphs with asterisk signs $\left({ }^{*}\right)$, indicating $p$-value of $p \leq 0.05\left(^{*}\right), p \leq 0.01\left(^{* *}\right)$, or $p \leq$ $\left.0.001{ }^{* * *}\right)$. No significance (n.s.) is displayed for $p>0.05$.

\section{Results}

\subsection{Bovine Myosatellite Cell Characterization}

Following a bovine muscle biopsy and cell expansion in vitro, characterization of proliferative cells by immunohistochemistry showed positive staining for the transcription factor Pax7, a nuclear identifier 
of myosatellite cell phenotype (Figure 1). Expression of Pax7 in all imaged cells indicates successful isolation of satellite cells from other cell types (i.e., fibroblasts), using the described pre-plating isolation method. After cultured cells reached confluency, they were differentiated for one week and stained for Troponin T. Expression of Troponin T, a sarcomeric protein involved in the contractile complex of skeletal muscle, indicates the myogenicity of isolated cells and verifies the successful isolation of a skeletal muscle precursor cell population.
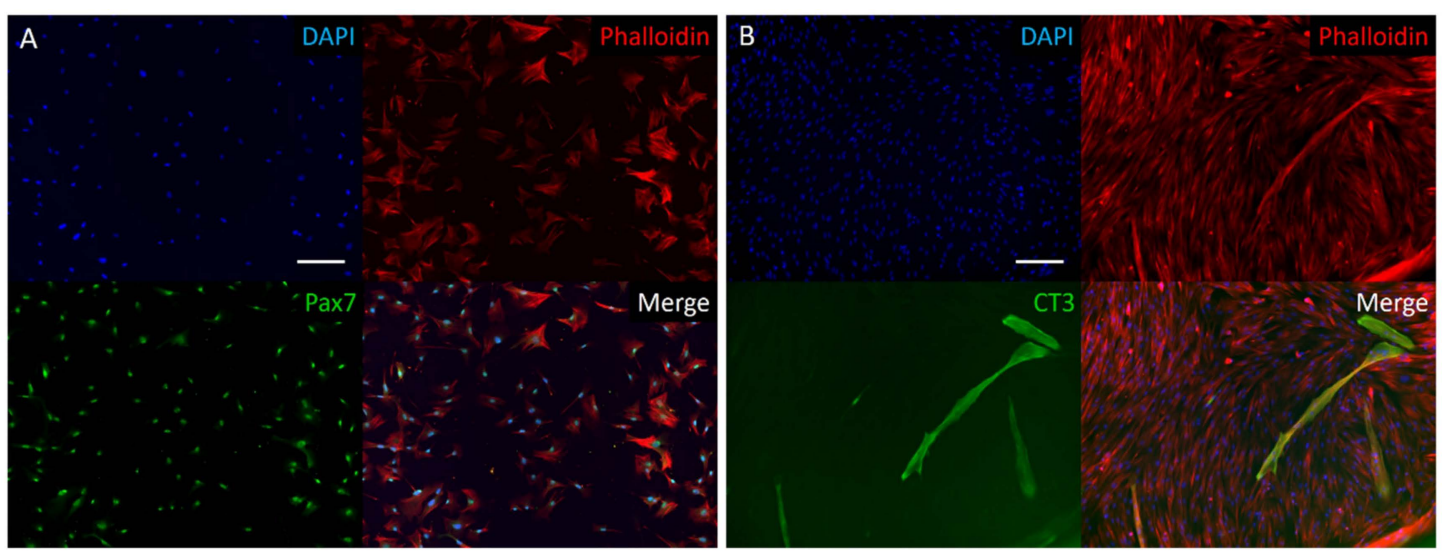

Figure 1. Two-dimensional immunofluorescence stain of isolated bovine muscle satellite cells (BSCs). (A) Proliferating bovine satellite stained for DAPI, actin cytoskeleton (Phalloidin), and Pax7, a nuclear marker of satellite cells. Stains show a highly pure satellite cell population, following isolation and pre-plating protocol. (B) Following one week of differentiation, cells were stained for DAPI, actin cytoskeleton (Phalloidin), and Troponin T (CT3), a marker of myogenesis. Scale bars are $200 \mu \mathrm{m}$.

\subsection{Myoglobin Increases Proliferation of BSCs}

The influence of $\mathrm{Mb}$ and $\mathrm{Hb}$ on the proliferation capacity of BSCs was observed by growing cells for one week with or without added heme proteins at different concentrations. From day three onward, $\mathrm{Mb}$ administered at $3 \mathrm{mg} / \mathrm{mL}$ resulted in a significant increase in proliferation compared to the untreated BSC group (Figure 2A). The Hb-treated group showed significantly decreased proliferation compared to the control group on day five and significantly decreased proliferation compared to the $\mathrm{Mb}$ group from day three on. Cell-doubling time in hours (calculated from initial cell number and cell number at day 7) was $41.67 \pm 2.55$ for BSCs, $43.28 \pm 0.66$ for BSC $+\mathrm{Hb}$, and $36.63 \pm 0.74$ for $\mathrm{BSC}+\mathrm{Mb}$.

Additionally, the effects of the concentration of heme protein on the proliferation potential of BSCs were analyzed. A linear decrease in proliferation was observed in the $\mathrm{Hb}$ group from $1 \mathrm{mg} / \mathrm{mL}$ to 3 $\mathrm{mg} / \mathrm{mL}$ and $5 \mathrm{mg} / \mathrm{mL}$, after one, three, and five days (Figure 2B). After seven days, significant differences only persisted between $3 \mathrm{mg} / \mathrm{mL}$ and $5 \mathrm{mg} / \mathrm{mL}$. The protein concentration of $\mathrm{Mb}$ had less effect on cell proliferation; however, on day seven, protein concentrations of $3 \mathrm{mg} / \mathrm{mL}$ and $5 \mathrm{mg} / \mathrm{mL}$ showed a significantly higher cell number compared to $1 \mathrm{mg} / \mathrm{mL}$ (Figure 2C). Taken together, these results indicate that addition of $\mathrm{Mb}$ to the culture media increases the proliferation capacity of BSCs, while addition of $\mathrm{Hb}$ has either no or a slightly negative effect on proliferation. Furthermore, proliferation effects were concentration dependent for $\mathrm{Hb}$, but less so for $\mathrm{Mb}$. 


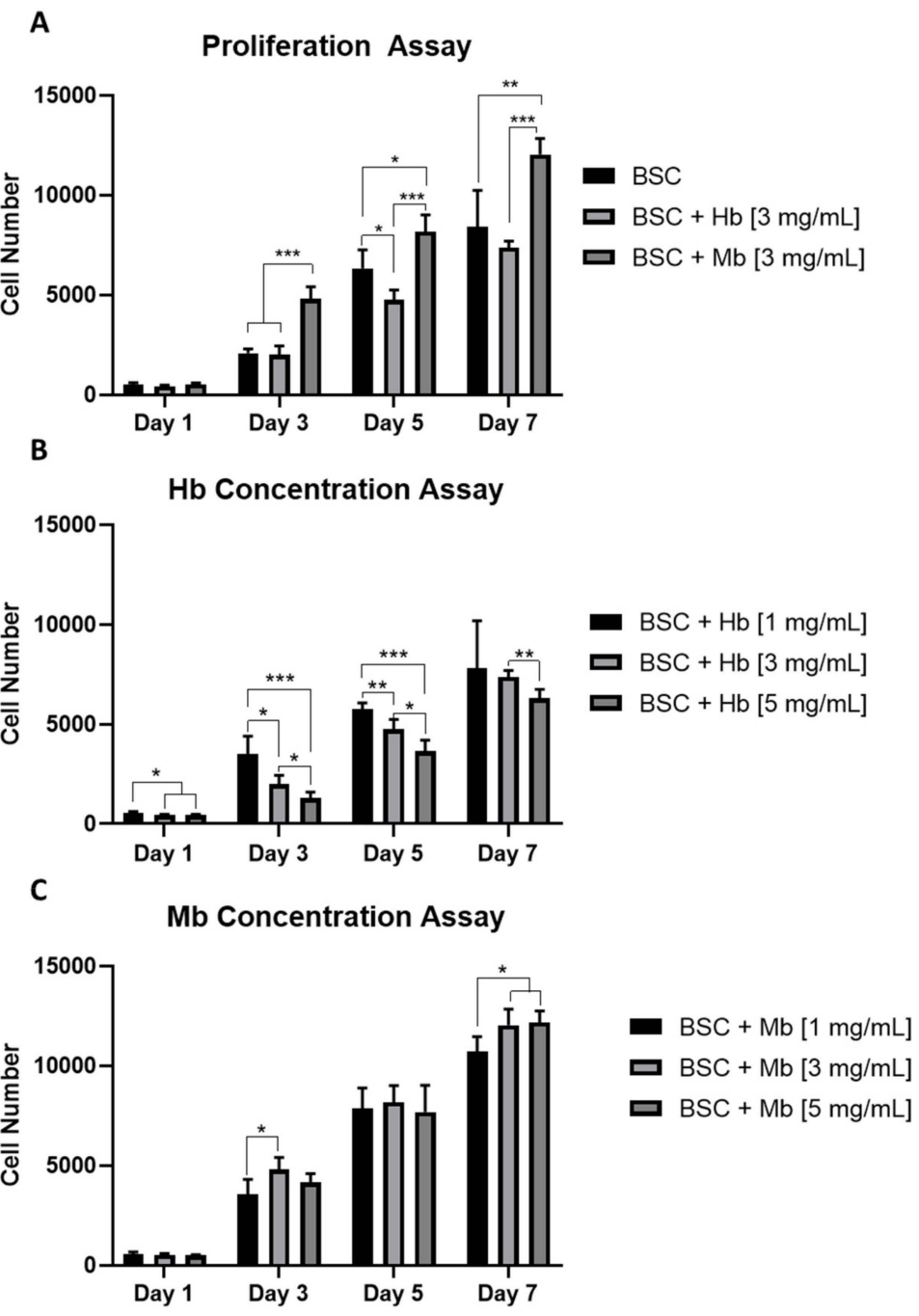

Figure 2. Proliferation of BSCs grown in the presence of different $\mathrm{Hb}$ or $\mathrm{Mb}$ concentrations in 2D. (A) Cell number of BSCs, BSCs $+3 \mathrm{mg} / \mathrm{mL} \mathrm{Hb}$, or BSCs $+3 \mathrm{mg} / \mathrm{mL} \mathrm{Mb}$, quantified with CyQuant reagent $(n=6)$ after one, three, five, and seven days. BSCs proliferation with different concentrations of $(\mathbf{B}) \mathrm{Hb}$ and $(C) \mathrm{Mb}$, at 1,3 or $5 \mathrm{mg} / \mathrm{mL}$ was observed $(n=6)$. Cell number was calculated from a standard curve prepared from cells seeded at known density. ${ }^{*} p \leq 0.05,{ }^{* *} p \leq 0.01,{ }^{* * *} p \leq 0.001$.

\subsection{BAM Formation and Dimensions}

Previous studies have utilized Velcro glued to the opposite side of culture dishes or well-plates to serve as "anchor points" for muscle cells [33,34]; however, this procedure is operator-dependent, work-intensive and difficult to standardize. For this study, anchor-point constructs were designed and 3D-printed in different configurations (for 3D models, see S1 File) to fit into individual wells of a 24-well plate. BSCs were incubated for nine days in a fibrin hydrogel in order to allow maturation and elongation to a BAM along the anchor point axis, and to observe coloration effects of heme proteins at a concentration of $3 \mathrm{mg} / \mathrm{mL}$ (Figure 3A). Elongation and compaction of the BAMs along the anchor points were already observed within the first few hours, reaching a stable form after $10 \mathrm{~h}$, both at the center (Video S1) and at the anchor points (Video S2) of the BAMs. To prevent fast degradation of the fibrin hydrogel by the cells, leading to detachment of BAMs from one or both anchor points, the fibrinolysis inhibitor aminocaproic acid (ACA) was added. A control group was grown, without ACA, to observe the effects of full hydrogel compaction. BAMs with ACA did not significantly differ in weight, thickness, or width (Figure $3 B$ ). When fibrinolysis was not inhibited (-ACA), the BAM weight was reduced by over $85 \%$ in all groups, showing that the hydrogel makes up a large part of the 
total muscle construct weight. Moreover, BAMs grown without ACA detached from the anchor point construct after 3-4 days of incubation. Even in the presence of fibrinolysis inhibitors (+ACA), muscle tissue weight was $80 \%-85 \%$ lower than the weight of the hydrogel without added cells, indicating partial gel compaction by the cells. Quantification of DNA content of the +ACA groups did not show significant differences among the groups (Figure 3C).

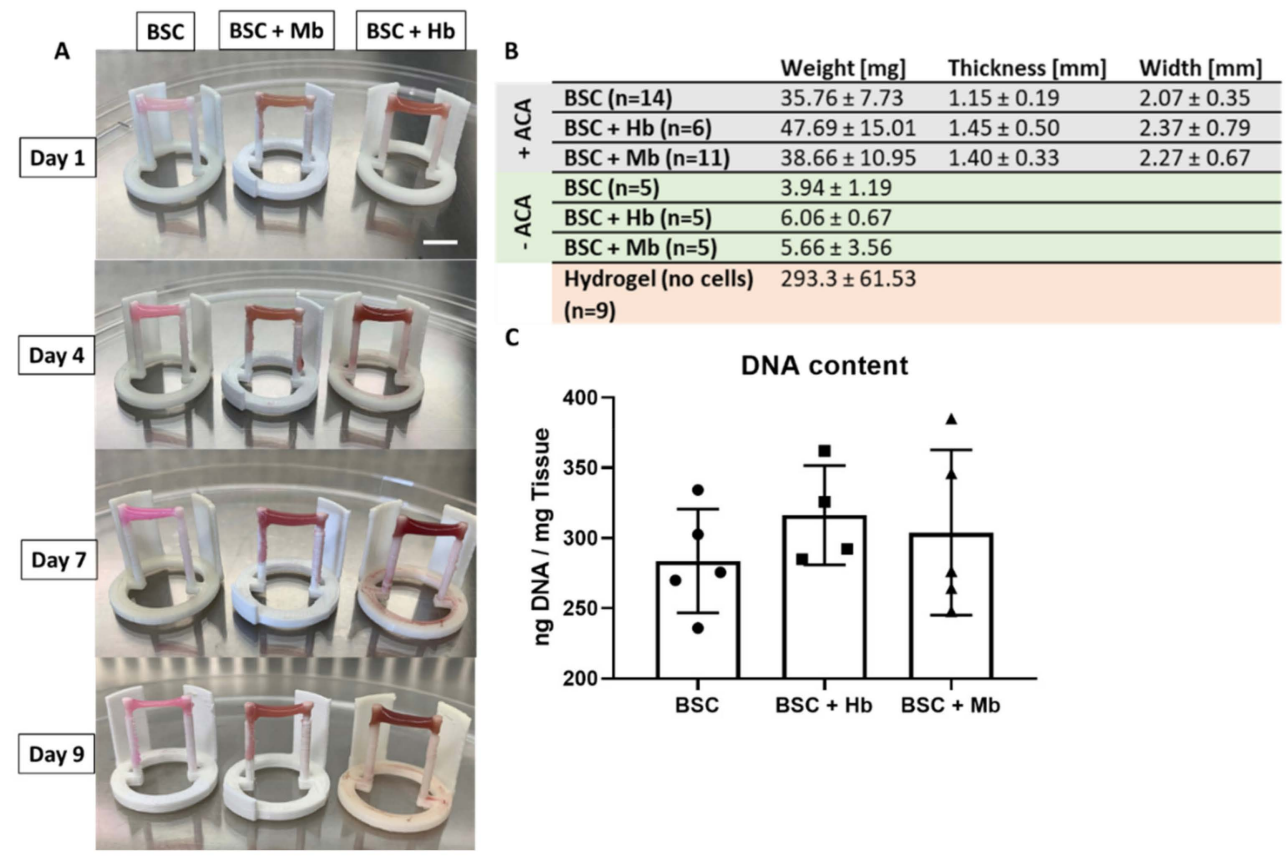

Figure 3. Properties of skeletal muscle tissue formation. (A) Representative images of bioartificial muscles (BAMs) generated from BSCs, BSCs $+\mathrm{Hb}$, and BSCs $+\mathrm{Mb}(3 \mathrm{mg} / \mathrm{mL}$ for both heme proteins) at different time points (one, four, seven, and nine days of incubation), showing increased color intensity in constructs with $\mathrm{Hb}$ and $\mathrm{Mb}$. Scale bar is $10 \mathrm{~mm}$. (B) Weight, width, and thickness of BAMs at time point of harvest are presented. Groups were compared against groups without added ACA (-ACA) and fibrin gel without added cells, both incubated for an equal amount of time, in the same conditions, for comparison of hydrogel compaction by the cells. Width and thickness could only be measured in the +ACA BAMs, as -ACA BAMs detached from anchor points and lost their physical form. (C) DNA of BSCs, BSCs $+\mathrm{Mb}(n=5)$, and BSCs $+\mathrm{Hb}(n=4)$ was extracted by proteinase $\mathrm{K}$ degradation, and absorbance was measured with NanoDrop.

\subsection{BAM Morphology, Differentiation, and Viability}

Differentiation of BSCs into mature muscle cells in fibrin constructs was visualized through staining for Troponin T. In the BSC and BSC + Mb group, early differentiation after eight days was observed as indicated by positive Troponin T staining of long, tube-like multi-nucleated cells (Figure 4). These myotubes were aligned, following the general alignment of all cells, as indicated by Phalloidin staining of the actin cytoskeleton. While both these groups showed several elongated cells that were positive for Troponin $\mathrm{T}$, the degree of myogenesis was moderate, and many cells did not appear to have formed myotubes. No major difference was seen in myogenicity between BSCs alone and BSCs treated with $\mathrm{Mb}$. In contrast, the BSC $+\mathrm{Hb}$ group showed no positive staining for Troponin $\mathrm{T}$, indicating little or no myogenic differentiation. At the same time, cells in these constructs appeared less elongated and aligned, indicating that cellular morphology in general was possibly adversely affected by the addition of $\mathrm{Hb}$. Hence, both the BSC and BSC $+\mathrm{Mb}$ group showed early myogenesis, which was not observed in the BSC $+\mathrm{Hb}$ group. 

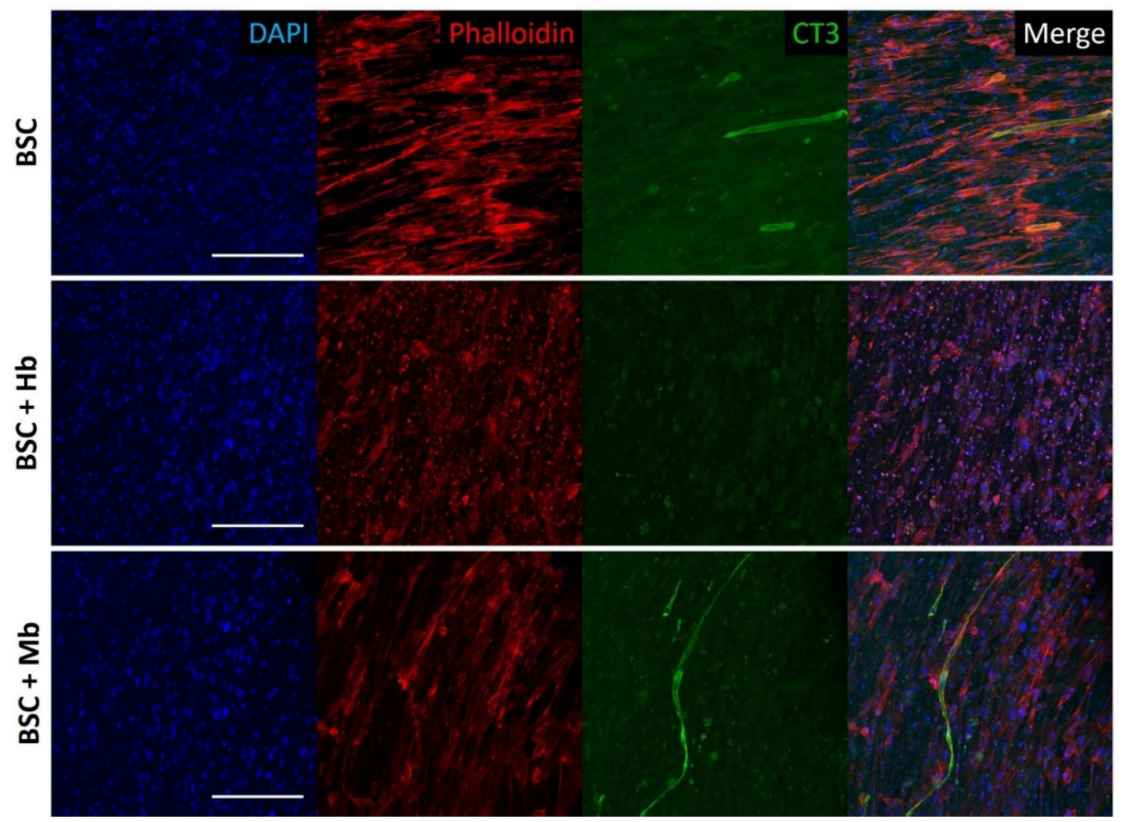

Figure 4. Confocal immunofluorescent imaging of BAMs. BAMs generated from BSC, BSC $+\mathrm{Hb}$, or BSC $+\mathrm{Mb}$ (3 mg/mL for both heme proteins) were stained after eight days of differentiation for DAPI, actin cytoskeleton (Phalloidin), and Troponin T (CT3), a marker of myogenesis. Images show multinucleated myotube formation in BSC and BSC $+\mathrm{Mb}$ constructs, though not in BSC $+\mathrm{Hb}$ constructs. Scale bars are $200 \mu \mathrm{m}$.

To visualize and compare cell viability among the different groups, BAMs were live-dead stained after eight days of incubation (Figure 5). The staining revealed no observable difference of live and dead cells among the different groups, suggesting that the addition of $\mathrm{Hb}$ and $\mathrm{Mb}$ does not impact cell viability at a visually detectable level. Green staining from calcein AM revealed a high number of viable cells in all groups, as well as elongated muscle-like morphologies and alignment along the anchor points. Red staining from ethidium homodimer indicated the presence of dead cells, particularly in the deeper layers of the tissue.

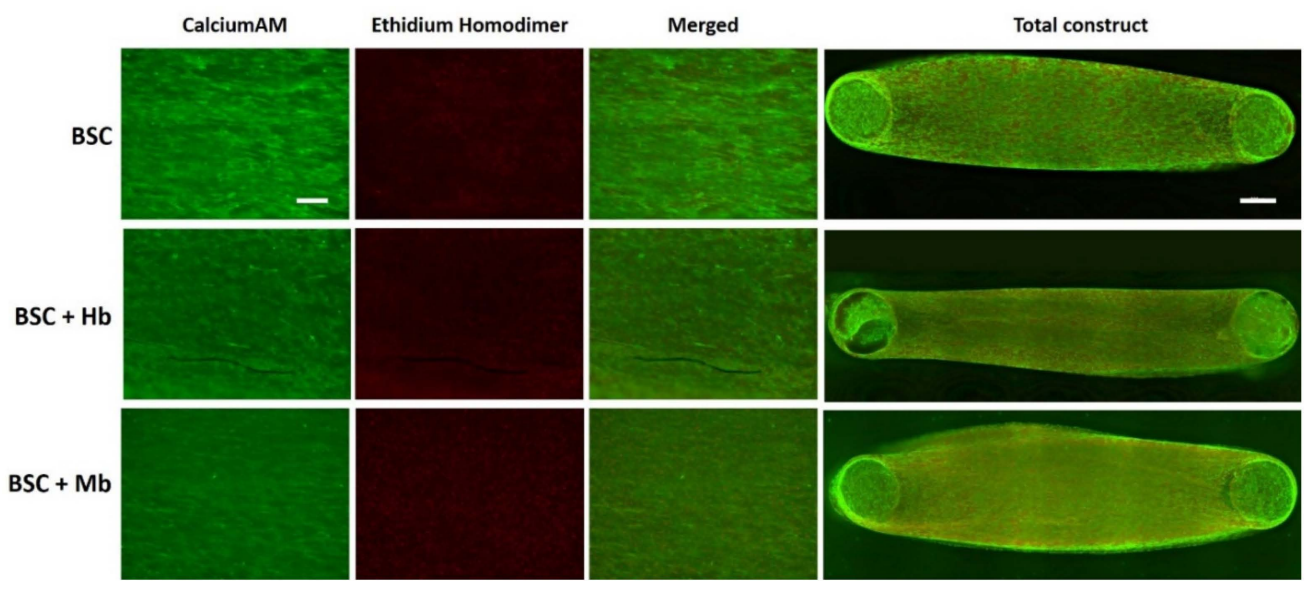

Figure 5. Live-dead staining of muscle constructs. BAMs generated from BSC, BSC $+\mathrm{Hb}$, or $\mathrm{BSC}+\mathrm{Mb}(3 \mathrm{mg} / \mathrm{mL}$ for both heme proteins) were stained with calcein AM (live cells, green) and ethidium homodimer (dead cells, red), to observe overall cell viability. Images were taken in green channel $(488 \mathrm{~nm})$ and red channel $(594 \mathrm{~nm})$, under identical microscope conditions, with z-Stack. For visualization of overall cell viability in total construct, $x$-y-stitching was performed. Scale bar in single channel images is $200 \mu \mathrm{m}$, and scale bar in the total construct is $1000 \mu \mathrm{m}$. 
From the calcein AM staining, cell alignment was quantified. We found that cell alignment was highest in the BSC group (61.2\%), significantly higher compared to the BSC $+\mathrm{Hb}(45.7 \%, p<0.0001)$ and the BSC $+\mathrm{Mb}$ group (51.1\%, $p=0.0005)$ (Figure 6), while significant, overall differences were small.

A

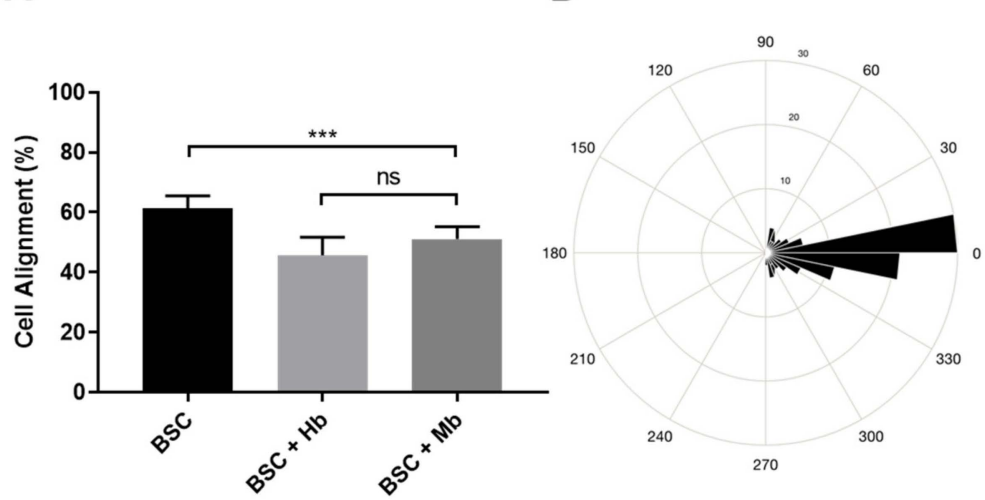

Figure 6. Alignment of BSCs. (A) BAMs generated from BSC, BSC $+\mathrm{Hb}$, or BSC $+\mathrm{Mb}(3 \mathrm{mg} / \mathrm{mL}$ for both heme proteins) were stained with calcein AM and imaged with a fluorescent microscope, after which images were processed on Fiji with the Directionality tool (Fourier method). Cell alignment was determined as the percentage of structures that were aligned between $-10^{\circ}$ and $10^{\circ}$ in relation to the axis of alignment $\left(0^{\circ}\right)$. Statistical significance was determined by one-way ANOVA and Tukey's multiple comparison post hoc test $(\alpha=0.05)$. Error bars are standard deviations $(n=9)$. (B) Average myotube orientation of the control group (BSC) was visualized by representative MatLab rose plot. ${ }^{* * *}$ $p \leq 0.001$.

Cell alignment was also confirmed via SEM imaging (Figure 7). The surface of both treated and untreated BAMs reveals the presence of aligned elongated structures. SEM imaging also demonstrates how BSC hydrogel compaction generates a dense cellular network without visible porous areas.
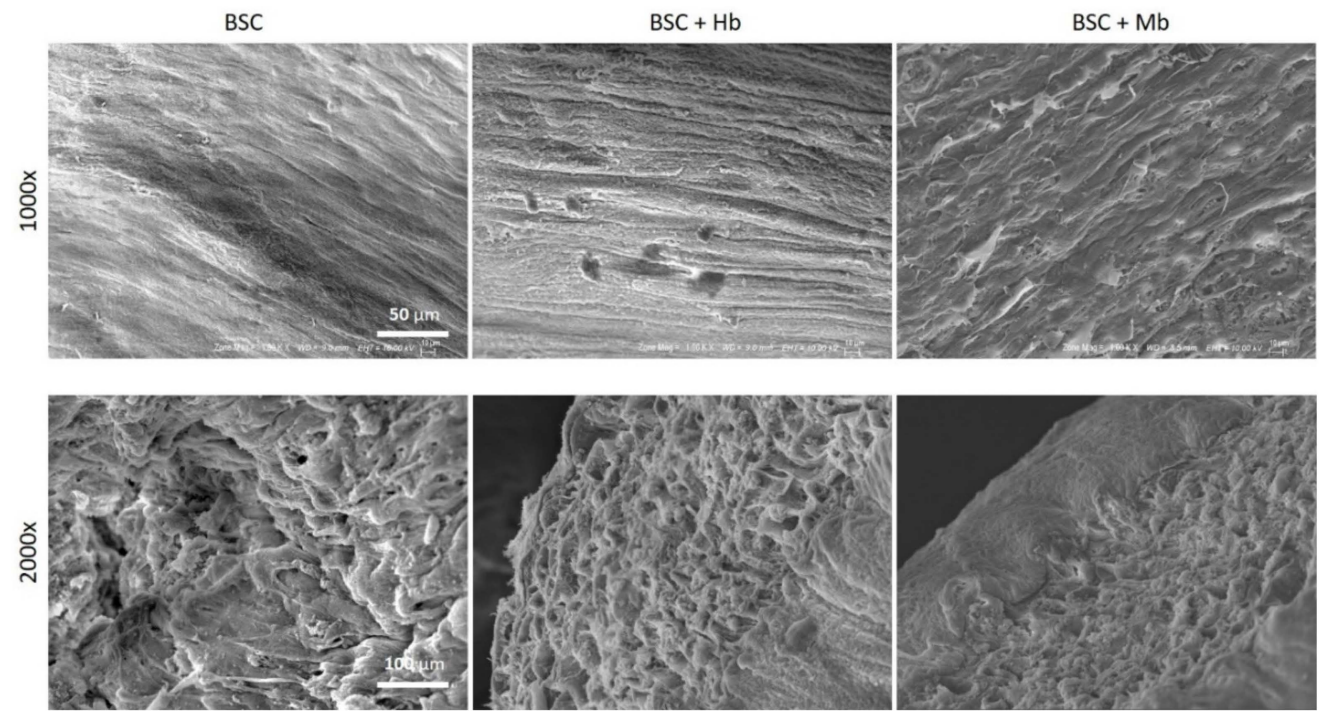

Figure 7. Scanning electron microscopy images of BAMs. BAMs generated from BSC, BSC $+\mathrm{Hb}$, or BSC $+\mathrm{Mb}(3 \mathrm{mg} / \mathrm{mL}$ for both heme proteins) were dehydrated and sputter coated with gold. Images were taken in $1000 \times$ magnification (scale bar $=50 \mu \mathrm{m}$ ) in the center of the tissue and $2000 \times$ magnification (scale bar $=100 \mu \mathrm{m}$ ) from the side of the tissue. 


\subsection{Biochemical Activity}

As an indicator of overall metabolic activity, we measured the media content of the signaling molecule NO and the secreted ECM molecule GAG (Figure 8). The NO level of the BSC $+\mathrm{Mb}$ group was slightly increased compared to the BSCs $(p=0.038)$ and BSC $+\mathrm{Hb}$ group $(p=0.015)$. Soluble GAG quantification showed a slight increase in the $\mathrm{BSC}+\mathrm{Mb}$ group compared with the $\mathrm{BSC}+\mathrm{Hb}$ group, but the increase was not significant $(p=0.07)$. Taken together, these results indicate a slightly increased metabolic activity in samples incubated with $\mathrm{Mb}$.
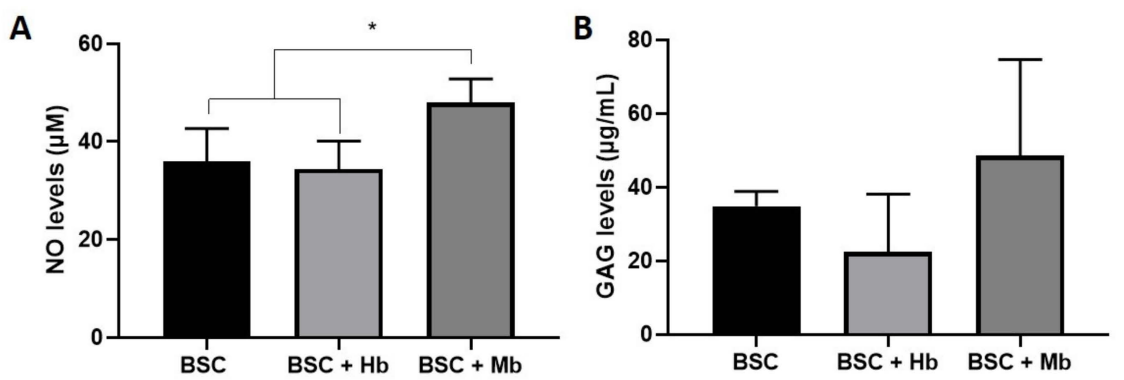

Figure 8. Biochemical analysis of secreted proteins by BAMs. Cell culture media from BAMs generated from BSC, BSC $+\mathrm{Hb}$, or BSC $+\mathrm{Mb}(3 \mathrm{mg} / \mathrm{mL}$ for both heme proteins) was removed after $72 \mathrm{~h}$ of incubation and measured for (A) Nitric Oxide $(n=5)$ and (B) Soluble GAGs $(n=6)$ content. * $p \leq 0.05$.

\subsection{Pigment Content and Color of BAMs}

Total pigment content (both $\mathrm{Hb}$ and $\mathrm{Mb}$ ) of the BAM groups and beef was calculated by absorbance measurement, following homogenization and pigment extraction (Figure 9A). Pigment content in beef was found to be $16.68 \pm 1.05 \mathrm{mg} / \mathrm{g}$, which corresponds to the expected heme content in young and mature cattle [35]. BSCs without added heme proteins contained $0.93 \pm 0.52 \mathrm{mg} / \mathrm{g}$, and $\mathrm{Hb}$ and $\mathrm{Mb}$ groups contained $2.89 \pm 0.89 \mathrm{mg} / \mathrm{g}$ and $1.77 \pm 0.25 \mathrm{mg} / \mathrm{g}$ respectively. While all BAM groups had significantly lower pigment content compared with beef, the BSC $+\mathrm{Hb}$ and the BSC $+\mathrm{Mb}$ group had a significantly higher pigment content compared to the BSC group. Taken together, these results show an increased pigment content in groups with added heme proteins, though at a lower level compared to the beef samples.

A

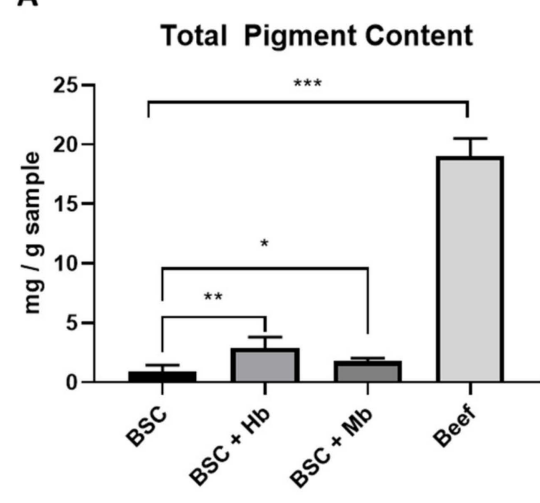

B

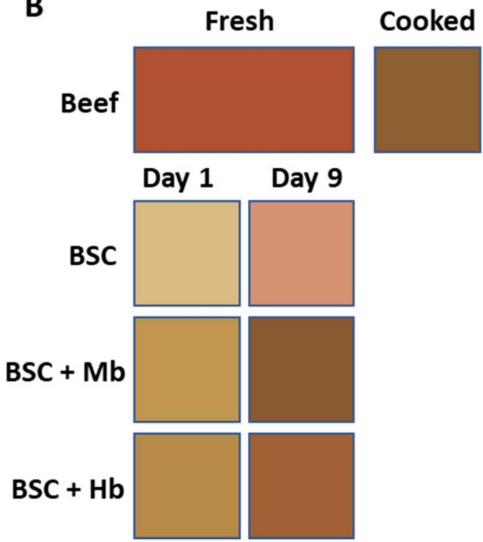

Figure 9. Pigment content and tissue coloration. (A) Total pigment content was quantified spectroscopically by homogenization of BAMs generated from BSC, BSC $+\mathrm{Hb}$, or BSC $+\mathrm{Mb}(3 \mathrm{mg} / \mathrm{mL}$ for both heme proteins) and beef ( $n=6$ for all groups) in a sodium phosphate buffer, leading to pigment release into the solution. The amount of pigment was calculated from a standard of $\mathrm{Hb}$ and $\mathrm{Mb}$. (B) Average $\mathrm{L}^{*} \mathrm{a}^{*} \mathrm{~b}^{*}$ values for BSC $(n=6), \mathrm{BSC}+\mathrm{Hb}(n=5)$, and BSC $+\mathrm{Mb}(n=6)$ and beef $(n=9)$ are displayed. Beef color is presented as fresh or cooked BAM color after incubation of one day or nine days. ${ }^{*} p \leq 0.05,{ }^{* *} p \leq 0.01,{ }^{* * *} p \leq 0.001$. 
The color of BAMs was analyzed by digital imaging after one and nine days of incubation. Images were analyzed for $\mathrm{L}^{*} \mathrm{a}^{*} \mathrm{~b}^{*}$ values with ImageJ and compared with fresh or cooked beef samples in terms of relative color similarity $(\Delta \mathrm{E}) . \Delta \mathrm{E}$ shows a high color similarity at low values (identical colors have a $\triangle \mathrm{E}$ value of zero) and a low color similarity with high values. Results show that heme containing BAMs always had a higher color similarity, both with fresh and cooked beef than the BSC control group (Figure 9B). Interestingly, even though BSC $+\mathrm{Hb}$ had the highest pigment content, the highest color similarity after nine days of incubation was found between cooked beef and BSC $+\mathrm{Mb}(\triangle \mathrm{E}=5.4$ $\pm 2.1)$, followed by $\mathrm{BSC}+\mathrm{Hb}(\triangle \mathrm{E}=9.0 \pm 0.9)$; meanwhile, the BSC group had a much lower similarity $(\Delta \mathrm{E}=24.5 \pm 2.4)$ (Table 1). There was a higher similarity to cooked meat than to fresh meat in all samples. This is a result of the heme redox form (met-form) utilized in this study, which is the redox form present in cooked beef. However, it is expected that different redox forms of heme proteins will have a similar coloration effect on BAMs. With longer incubation times, a decrease in the $\mathrm{L}^{*}$ value and an increase in the $a^{*}$ and $b^{*}$ values were observed in all BAM samples, approaching the values of cooked beef. This demonstrates the importance of longer incubation times with heme proteins to facilitate the maturation of tissue and increased coloration. Taken together, these results show that the cultivation of BAMs with heme proteins leads to a higher color similarity with beef than when no heme proteins are applied, which was especially evident for the Mb application.

Table 1. Color of BAMs generated from BSC, BSC $+\mathrm{Hb}$, or BSC $+\mathrm{Mb}$ ( $3 \mathrm{mg} / \mathrm{mL}$ for both heme proteins) after one or nine days of incubation, compared with fresh and cooked beef samples.

\begin{tabular}{ccccccccc}
\hline & \multicolumn{2}{c}{ Beef } & \multicolumn{2}{c}{ BSC } & \multicolumn{2}{c}{ BSC + Hb } & \multicolumn{2}{c}{ BSC + Mb } \\
\cline { 2 - 9 } & Fresh & Cooked & Day 1 & Day 9 & Day 1 & Day 9 & Day 1 & Day 9 \\
\hline $\mathbf{L}^{*}$ & $45.9 \pm 3.2$ & $44.5 \pm 0.9$ & $76.4 \pm 1.5$ & $66.3 \pm 3.7$ & $60.9 \pm 1.1$ & $47.5 \pm 1.7$ & $64.5 \pm 1.5$ & $42.8 \pm 4.1$ \\
$\mathbf{a}^{*}$ & $37.2 \pm 0.6$ & $12.9 \pm 0.9$ & $3.5 \pm 0.9$ & $20.8 \pm 3.3$ & $11.4 \pm 1.0$ & $20.9 \pm 0.9$ & $8.1 \pm 0.7$ & $15.6 \pm 1.0$ \\
$\mathbf{b}^{*}$ & $37.7 \pm 0.8$ & $33.7 \pm 0.7$ & $32.7 \pm 0.9$ & $26.8 \pm 0.7$ & $42.3 \pm 0.6$ & $36.1 \pm 0.4$ & $43.1 \pm 1.3$ & $31.7 \pm 1.4$ \\
\hline$\Delta$ E (fresh) a & & & $45.7 \pm 1.5$ & $28.4 \pm 4.2$ & $30.1 \pm 1.1$ & $16.4 \pm 0.9$ & $34.9 \pm 1.1$ & $23.0 \pm 1.3$ \\
$\Delta$ E (cooked) & & & $33.3 \pm 1.6$ & $24.5 \pm 2.4$ & $18.6 \pm 0.8$ & $9.0 \pm 0.9$ & $22.6 \pm 1.2$ & $5.4 \pm 2.1$ \\
\hline
\end{tabular}

a $\Delta \mathrm{E}$ (fresh) represents color similarity of a given group with fresh beef, and $\Delta \mathrm{E}$ (cooked) represents color similarity with cooked beef. Values for $L^{*}$ (lightness), $a^{*}$ (red/green spectra), and $b^{*}$ (blue/yellow spectra) are presented. The relative color difference between BAMs and either fresh or cooked beef is expressed as $\Delta \mathrm{E}$. A value of $\Delta \mathrm{E}=0$ represents identical colors, while higher values represent a greater difference in color.

\section{Discussion}

Cell-based meat is a promising technology to utilize muscle-tissue engineering for food production. In this study, we investigated the role of extracellular added heme proteins $\mathrm{Hb}$ and $\mathrm{Mb}$ on the development of cell-based meat. We chose these specific heme proteins, as they are either already applied in food products $(\mathrm{Hb})$ or highly abundant in muscle tissue in vivo $(\mathrm{Mb})$. Heme proteins are of interest for in vitro beef production for several reasons. First, the content of heme is responsible for the typical color of meat, and added heme proteins would ideally diminish the necessity of other colorants and resemble the native color of meat more precisely. Second, heme proteins are in part responsible for the slightly metallic taste of beef and can increase the iron content of the final product [30]. Third, Mb has very low expression levels in undifferentiated muscle cells [24,36], but has important functions within differentiated muscle tissue; therefore, incorporation of extracellular $\mathrm{Mb}$ might influence biochemical activity and cell proliferation. Our results show that heme proteins have an effect on the proliferation and coloration of the tissue, with $\mathrm{Mb}$ showing a more beneficial outcome.

We found that the proliferation of BSCs in 2D was increased in the presence of $\mathrm{Mb}$, while $\mathrm{Hb}$ had no, or a slightly negative, effect on cell proliferation. We hypothesize that added $\mathrm{Mb}$ increases oxygen transport to mitochondria and subsequent biochemical activity, which could explain the observed increased proliferation potential. To our knowledge, Mb-induced increased proliferation of myosatellite cells was not yet described. However, in other cell types, $\mathrm{Mb}$ does not seem to stimulate proliferation. Increased $\mathrm{Mb}$ expression in human cancer cells decreases cell proliferation due to interaction with mitochondria [37]. In cell culture, both free $\mathrm{Hb}$ and $\mathrm{Mb}$ were shown to cause damage 
to renal cells, starting from concentrations as low as $1 \mathrm{mg} / \mathrm{mL}$ [38]. A study observing the effect of $\mathrm{Hb}$ on smooth muscle cells showed reduced proliferation potential at concentrations of $100 \mu \mathrm{M}$ (equivalent to $6.5 \mathrm{mg} / \mathrm{mL}$ ) due to free radicals, which might explain the slightly decreased proliferation of BSCs upon $\mathrm{Hb}$ addition. Hemoglobin was shown to cause damaging effects to tissue due to NO depletion and hemin release [39]. Free heme is known to cause toxicity due to the oxidative potential of free iron, as observed in vivo in certain kidney diseases in humans [38,40]. Thus, the beneficial effect of $\mathrm{Mb}$ on myosatellite cell proliferation seems to be cell-specific. Along with other methods, such as genetical engineering of cells [41], the addition of $\mathrm{Mb}$ to the cell culture media might therefor be of value for large-scale cell expansion.

After nine days of incubation in a fibrin hydrogel, BAMs had average tissue dimensions similar to previously published results [42,43]; however, some groups have achieved larger constructs with different approaches, such as specialized bioreactors [44], cell-sheet stacking [45], 3D bioprinting [46], or coculture systems with endothelial cells [47]. The size of constructs, however, depends largely on initial cell number, scaffold volume, and cultivation method. Fibrin hydrogel in this study was animal-derived; however, recombinant fibrin formulations were also previously described [48,49]. After eight days of incubation in differentiation media, early myogenesis of BSCs and BSCs $+\mathrm{Mb}$ was observed by Troponin $\mathrm{T}$ staining. It is possible that, given more time, additional cells may have fused [43]. However, for cell-based meat development, full differentiation of skeletal muscle cells might not be required [50]. SEM imaging and cell alignment quantification furthermore confirmed fibrillar and dense surface structure, comparable to results published by other groups [51,52], and opposed to fibrin hydrogels grown without the presence of cells, which show greater porosity [53], which is beneficial, as fibrillar structures are integral for meat texture. Cell death was observed in deeper layers of the tissue, which is commonly reported, as tissues without blood vessels or perfusable chambers show decreased viability beyond 100-200 $\mu \mathrm{m}$ of the tissue surface, due to an insufficient supply of oxygen and nutrients [54]. Furthermore, high cell-seeding densities, additionally increased by compaction of the hydrogel, are known to cause stress in cell culture, leading to apoptosis. These results underline the importance of development of tissue vascularization or perfusion methods [55]. Biochemical activity appeared to be slightly increased in Mb-treated groups, in terms of secreted NO and GAGs. Skeletal muscle cells produce NO by nitric oxide synthases. NOs are gaseous free radicals that can freely transverse cell membranes and act as signaling molecules, which are associated with muscle repair and regeneration [56,57]. GAGs are part of proteoglycans and have an important function in the binding and storage of growth factors; furthermore, they act as a protein anchorage present in the extracellular matrix to facilitate cell-substrate adhesion. The release of different GAGs, e.g., hyaluronic acid, heparan sulfate, chondroitin sulfate, and chondroitin, by skeletal muscle cells was previously reported [58-60]. Increased secretion of these molecules might indicate higher metabolic activity in the muscle tissue.

Globally, a lot of research was performed on color and color stability of meat due to commercial interest in proper meat packaging and display; however, changing the color of bioengineered tissue constructs has evoked little scientific interest to date. To compare coloration between samples, we applied digital imaging methods, which delivered reliable results for meat and other food samples [61-64]. The color of meat is mainly influenced by the content and redox-form of myoglobin, with oxymyoglobin being bright red and metmyoglobin being brown-red [21]. In this study, we utilized the $\mathrm{Hb}$ and $\mathrm{Mb}$ in the met-form due to commercial availability, which led to a darker coloration compared to fresh beef, but a very similar color compared with cooked beef, especially when $\mathrm{Mb}$ was applied. This is due to oxidation of oxymyoglobin to metmyoglobin during the cooking process in beef. Similar coloration can be expected with different redox forms of heme proteins, and heme proteins can be stabilized with a variety of methods to obtain the oxymyoglobin form [25]. While heme containing BAMs had a more similar color to cooked meat, the color differences were still evident. This could be explained by an insufficient concentration of heme proteins; the cultivation system used, as meat is a multi-cellular tissue and does not solely consist of muscle cells; and by the fibrin hydrogel, which does 
not properly represent the extracellular matrix of meat. Given these limitations, further optimization of heme protein application for a more sophisticated cell-based meat product might yield a higher color similarity. Taken together, our results show that heme proteins can be applied in cell-based meat production to drive the color of both raw and cooked cell-based meat. Apart from the coloration, heme proteins might also influence the flavor of the product, as currently applied for the plant-based "Impossible Burger".

Due to availability, heme proteins applied in this study were animal-derived. As a requirement for cell-based meat is the avoidance of animal products, plant-extracted or recombinant heme proteins are of higher interest for actual production processes. Other strategies to increase heme protein content might include a process design that enables higher myoglobin expression by muscle cells. For example, the restriction of iron leads to a 0.5-fold increase in myoglobin content in mice muscle tissue compared to untreated animals [65]. An almost 2-fold increase in myoglobin content in C2C12 cells in 5\% lipid supplemented growth media was reported [66]. Up to a 15-fold increase in myoglobin expression in vascular smooth muscle cells was found when treated with nitric oxide [67]. Different groups showed increased myoglobin expression in muscle cells from the addition of $0.5 \mathrm{mM}$ of acetic acid [68] or ursolic acid [69] to the cell culture media. Previous studies also showed that hypoxia leads to increased myoglobin expression [36], and hypoxic cell culture conditions increased BSC proliferation and differentiation [27]. However, muscle cells are one of only a few cell types that maintain cell proliferation under hypoxia, which must be taken into consideration in coculture systems with endothelial cells and adipocytes [70]. These or other changes in process parameters might be of interest to increase myoglobin production by the cells, but difficulties might arise when taking coculture systems, toxicity of certain supplements, or feasible production conditions and/or costs into account.

\section{Conclusions}

We demonstrated that heme proteins, added directly to the cell culture media can influence proliferation of bovine skeletal muscle cells and can lead to a more meat-like coloration of 3D skeletal muscle tissues cultivated in vitro for the generation of cell-based meat. Furthermore, heme protein $\mathrm{Mb}$ had preferable attributes compared to $\mathrm{Hb}$ as a cell-culture media additive. This study shows the potential of heme proteins to be utilized in the development of cell-based meat.

Supplementary Materials: The following are available online at http://www.mdpi.com/2304-8158/8/10/521/s1. S1 File: 3D models of anchor point constructs in different configurations for 24-well plate. Video S1: Time lapse of hydrogel compaction by skeletal muscle cells in the middle of the BAM. Video S2: Time lapse of hydrogel compaction by skeletal muscle cells on the anchor point of the BAM.

Author Contributions: Conceptualization, R.S. and D.L.K.; Methodology, R.S., J.Y., A.S., and N.R.; Software, R.S. and J.Y.; Validation, R.S., J.Y., A.S., and N.R.; Formal analysis, R.S., and A.S.; Investigation, R.S., J.Y., A.S., and N.R.; Resources, D.L.K.; data Curation, R.S. and A.S.; Writing-original draft preparation, R.S., J.Y., A.S., N.R., D.L.K., and P.F.; Writing-review and editing, R.S., D.L.K., and P.F.; Visualization, R.S., J.Y., and A.S.; Supervision, D.L.K. and P.F.; Project administration, D.L.K.; Funding acquisition, D.L.K. and P.F.

Funding: We thank the NIH (P41EB002520) and New Harvest for support of this work. R.S. is furthermore supported by the European Union's Horizon 2020 research and innovation program under the Marie Skłodowska-Curie grant agreement No 722779, conducted within the "Training 4 Cell Regenerative Medicine" (T4CRM) network.

Conflicts of Interest: The authors declare no conflicts of interest.

\section{References}

1. Tuomisto, H.L. The eco-friendly burger. EMBO Rep. 2019, 20, e47395. [CrossRef] [PubMed]

2. Godfray, H.C.J.; Aveyard, P.; Garnett, T.; Hall, J.W.; Key, T.J.; Lorimer, J.; Pierrehumbert, R.T.; Scarborough, P.; Springmann, M.; Jebb, S.A. Meat consumption, health, and the environment. Science 2018, 361, eaam5324. [CrossRef] [PubMed] 
3. Cederberg, C.; Persson, U.M.; Neovius, K.; Molander, S.; Clift, R. Including Carbon Emissions from Deforestation in the Carbon Footprint of Brazilian Beef. Environ. Sci. Technol. 2011, 45, 1773-1779. [CrossRef]

4. Machovina, B.; Feeley, K.J.; Ripple, W.J. Biodiversity conservation: The key is reducing meat consumption. Sci. Total. Environ. 2015, 536, 419-431. [CrossRef] [PubMed]

5. Mathew, A.G.; Cissell, R.; Liamthong, S. Antibiotic Resistance in Bacteria Associated with Food Animals: A United States Perspective of Livestock Production. Foodborne Pathog. Dis. 2007, 4, 115-133. [CrossRef] [PubMed]

6. Jeong, S.-H.; Kang, D.-J.; Lim, M.-W.; Kang, C.-S.; Sung, H.-J. Risk Assessment of Growth Hormones and Antimicrobial Residues in Meat. Toxicol. Res. 2010, 26, 301-313. [CrossRef]

7. Ramatla, T.; Ngoma, L.; Adetunji, M.; Mwanza, M. Evaluation of Antibiotic Residues in Raw Meat Using Different Analytical Methods. Antibiotics 2017, 6, 34. [CrossRef]

8. Pajalunga, D.; Mazzola, A.; Puggioni, E.; Crescenzi, M. Non-proliferation as an active state: Conceptual and practical implications. Cell Cycle 2007, 6, 1414-1417. [CrossRef]

9. Wang, H.; Lööf, S.; Borg, P.; Nader, G.A.; Blau, H.M.; Simon, A. Turning terminally differentiated skeletal muscle cells into regenerative progenitors. Nat. Commun. 2015, 6, 7916. [CrossRef]

10. Yin, H.; Price, F.; Rudnicki, M.A. Satellite Cells and the Muscle Stem Cell Niche. Physiol. Rev. 2013, 93, $23-67$. [CrossRef]

11. Qazi, T.H.; Mooney, D.J.; Pumberger, M.; Geißler, S.; Duda, G.N. Biomaterials based strategies for skeletal muscle tissue engineering: Existing technologies and future trends. Biomaterials 2015, 53, 502-521. [CrossRef] [PubMed]

12. Urciuolo, A.; De Coppi, P. Decellularized Tissue for Muscle Regeneration. Int. J. Mol. Sci. 2018, 19, 2392. [CrossRef] [PubMed]

13. Gershlak, J.R.; Hernandez, S.; Fontana, G.; Perreault, L.R.; Hansen, K.J.; Larson, S.A.; Binder, B.Y.K.; Dolivo, D.M.; Yang, T.; Dominko, T.; et al. Crossing kingdoms: Using decellularized plants as perfusable tissue engineering scaffolds. Biomaterials 2017, 125, 13-22. [CrossRef] [PubMed]

14. Ostrovidov, S.; Hosseini, V.; Ahadian, S.; Fujie, T.; Parthiban, S.P.; Ramalingam, M.; Bae, H.; Kaji, H.; Khademhosseini, A. Skeletal Muscle Tissue Engineering: Methods to Form Skeletal Myotubes and Their Applications. Tissue Eng. Part B Rev. 2014, 20, 403-436. [CrossRef] [PubMed]

15. Post, M.J. Cultured beef: Medical technology to produce food. J. Sci. Food Agric. 2014, 94, $1039-1041$. [CrossRef] [PubMed]

16. Post, M.J. An alternative animal protein source: Cultured beef. Ann. N. Y. Acad. Sci. 2014, 1328, $29-33$. [CrossRef]

17. Syverud, B.C.; VanDusen, K.W.; Larkin, L.M. Growth Factors for Skeletal Muscle Tissue Engineering. Cells Tissues Organs 2016, 202, 169-179. [CrossRef]

18. Bekhit, A.; Faustman, C. Metmyoglobin reducing activity. Meat Sci. 2005, 71, 407-439. [CrossRef]

19. Wittenberg, J.B.; Wittenberg, B.A. Myoglobin function reassessed. J. Exp. Biol. 2003, 206, 2011-2020. [CrossRef]

20. Wilson, M.T.; Reeder, B.J. Oxygen-binding haem proteins. Exp. Physiol. 2008, 93, 128-132. [CrossRef]

21. Suman, S.P.; Joseph, P. Myoglobin Chemistry and Meat Color. Annu. Rev. Food Sci. Technol. 2013, 4, 79-99. [CrossRef] [PubMed]

22. Calkins, C.; Hodgen, J. A fresh look at meat flavor. Meat Sci. 2007, 77, 63-80. [CrossRef] [PubMed]

23. Siegrist, M.; Sütterlin, B. Importance of perceived naturalness for acceptance of food additives and cultured meat. Appetite 2017, 113, 320-326. [CrossRef]

24. Graber, S.G.; Woodworth, R.C. Myoglobin expression in L6 muscle cells. Role of differentiation and heme. J. Biol. Chem. 1986, 261, 9150-9154. [PubMed]

25. Appiah, J.; Peggy, Y.-H. The Use of Blood and Derived Products as Food Additives. Food Addit. 2012. Available online: http://www.intechopen.com/books/food-additive/the-use-of-blood-and-derived-productsas-food-additives (accessed on 22 February 2012).

26. Martínez-Navarrete, N.; Camacho, M.; Martínez-Lahuerta, J.; Martínez-Monzó, J.; Fito, P.; Camacho, M.D.M. Iron deficiency and iron fortified foods-A review. Food Res. Int. 2002, 35, 225-231. [CrossRef]

27. Kook, S.; Son, Y.; Lee, K.; Lee, H.; Chung, W.; Choi, K.; Lee, J. Hypoxia affects positively the proliferation of bovine satellite cells and their myogenic differentiation through up-regulation of MyoD. Cell Biol. Int. 2008, 32, 871-878. [CrossRef] [PubMed] 
28. Longeville, S.; Stingaciu, L.-R. Hemoglobin diffusion and the dynamics of oxygen capture by red blood cells. Sci. Rep. 2017, 7, 10448. [CrossRef]

29. Eshbach, M.L.; Kaur, A.; Rbaibi, Y.; Tejero, J.; Weisz, O.A. Hemoglobin inhibits albumin uptake by proximal tubule cells: Implications for sickle cell disease. Am. J. Physiol. Physiol. 2017, 312, C733-C740. [CrossRef]

30. Fraser, R.; Brown, P.O.; Karr, J.; Holz-Schietinger, C.; Cohn, E. Methods and Compositions for Affecting the Flavor and Aroma Profile of Consumables. U.S. Patent 9,943,096, 2014. Available online: https://patentscope.wipo.int/search/en/detail.jsf;jsessionid=6F62A6BF5AC11D20AE4CEB45EEE37F73. wapp1nA?docId=WO2014110532\&tab=PCTDESCRIPTION\&maxRec=1000 (accessed on 19 October 2019).

31. Warris, P.D. The extraction of haem pigments from fresh meat. Int. J. Food Sci. Technol. 2007, 14, 75-80. [CrossRef]

32. Krzywicki, K. The determination of haem pigments in meat. Meat Sci. 1982, 7, 29-36. [CrossRef]

33. Krieger, J.; Park, B.-W.; Lambert, C.R.; Malcuit, C. 3D skeletal muscle fascicle engineering is improved with TGF- $\beta 1$ treatment of myogenic cells and their co-culture with myofibroblasts. PeerJ 2018, 6, e4939. [CrossRef] [PubMed]

34. Van der Schaft, D.W.J.; van Spreeuwel, A.C.C.; Boonen, K.J.M.; Langelaan, M.L.P.; Bouten, C.V.C.; Baaijens, F.P.T. Engineering skeletal muscle tissues from murine myoblast progenitor cells and application of electrical stimulation. J. Vis. Exp. 2013, e4267. [CrossRef] [PubMed]

35. Seideman, S.C.; Cross, H.R.; Smith, G.C.; Durland, P.R. Factors associated with fresh meat color: A review. J. Food Qual. 1984, 6, 211-237. [CrossRef]

36. Kanatous, S.B.; Mammen, P.P.A. Regulation of myoglobin expression. J. Exp. Biol. 2010, 213, $2741-2747$. [CrossRef]

37. Braganza, A.; Quesnelle, K.; Arnotti, L.; Singh, S.; Shiva, S. Myoglobin induces mitochondrial fusion to inhibit cancer cell proliferation and tumor growth. Free Radic. Biol. Med. 2018, 120, S37. [CrossRef]

38. Zager, R.A.; Burkhart, K. Myoglobin toxicity in proximal human kidney cells: Roles of $\mathrm{Fe}, \mathrm{Ca}^{2+}, \mathrm{H}_{2} \mathrm{O}_{2}$, and terminal mitochondrial electron transport. Kidney Int. 1997, 51, 728. [CrossRef]

39. Schaer, D.J.; Buehler, P.W.; Alayash, A.I.; Belcher, J.D.; Vercellotti, G.M. Hemolysis and free hemoglobin revisited: Exploring hemoglobin and hemin scavengers as a novel class of therapeutic proteins. Blood 2013, 121, 1276-1284. [CrossRef]

40. Reeder, B.J.; Sharpe, M.A.; Kay, A.D.; Kerr, M.; Moore, K.; Wilson, M.T.; Reeder, B. Toxicity of myoglobin and haemoglobin: Oxidative stress in patients with rhabdomyolysis and subarachnoid haemorrhage. Biochem. Soc. Trans. 2002, 30, 745-748. [CrossRef]

41. Ding, S.; Swennen, G.N.M.; Messmer, T.; Gagliardi, M.; Molin, D.G.M.; Li, C.; Zhou, G.H.; Post, M.J. Maintaining bovine satellite cells stemness through p38 pathway. Sci. Rep. 2018, 8, 10808. [CrossRef]

42. Maffioletti, S.M.; Sarcar, S.; Henderson, A.B.; Mannhardt, I.; Pinton, L.; Moyle, L.A.; Steele-Stallard, H.; Cappellari, O.; Wells, K.E.; Ferrari, G.; et al. Three-Dimensional Human iPSC-Derived Artificial Skeletal Muscles Model Muscular Dystrophies and Enable Multilineage Tissue Engineering. Cell Rep. 2018, 23, 899-908. [CrossRef]

43. Prüller, J.; Mannhardt, I.; Eschenhagen, T.; Zammit, P.S.; Figeac, N. Satellite cells delivered in their niche efficiently generate functional myotubes in three-dimensional cell culture. PLoS ONE 2018, 13, e0202574. [CrossRef] [PubMed]

44. Heher, P.; Maleiner, B.; Prüller, J.; Teuschl, A.H.; Kollmitzer, J.; Monforte, X.; Wolbank, S.; Redl, H.; Rünzler, D.; Fuchs, C. A novel bioreactor for the generation of highly aligned 3D skeletal muscle-like constructs through orientation of fibrin via application of static strain. Acta Biomater. 2015, 24, 251-265. [CrossRef] [PubMed]

45. Sasagawa, T.; Shimizu, T.; Sekiya, S.; Haraguchi, Y.; Yamato, M.; Sawa, Y.; Okano, T. Design of prevascularized three-dimensional cell-dense tissues using a cell sheet stacking manipulation technology. Biomaterials 2010, 31, 1646-1654. [CrossRef]

46. Kim, J.H.; Seol, Y.-J.; Ko, I.K.; Kang, H.-W.; Lee, Y.K.; Yoo, J.J.; Atala, A.; Lee, S.J. 3D Bioprinted Human Skeletal Muscle Constructs for Muscle Function Restoration. Sci. Rep. 2018, 8, 12307. [CrossRef] [PubMed]

47. Gholobova, D.; Decroix, L.; Van Muylder, V.; Desender, L.; Gerard, M.; Carpentier, G.; VanDenburgh, H.; Thorrez, L. Endothelial Network Formation Within Human Tissue-Engineered Skeletal Muscle. Tissue Eng. Part A 2015, 21, 2548-2558. [CrossRef] [PubMed] 
48. Wang, O.; Ismail, A.; Fabian, F.M.; Lin, H.; Li, Q.; Elowsky, C.; Carlson, M.A.; Burgess, W.; Velander, W.H.; Kidambi, S.; et al. A totally recombinant fibrin matrix for mesenchymal stem cell culture and delivery. J. Biomed. Mater. Res. Part A 2018, 106, 3135-3142. [CrossRef]

49. Calcaterra, J.; Van Cott, K.E.; Butler, S.P.; Gil, G.C.; Germano, M.; van Veen, H.A.; Nelson, K.; Forsberg, E.J.; Carlson, M.A.; Velander, W.H. Recombinant Human Fibrinogen That Produces Thick Fibrin Fibers with Increased Wound Adhesion and Clot Density. Biomacromolecules 2013, 14, 169-178. [CrossRef]

50. Stephens, N.; Di Silvio, L.; Dunsford, I.; Ellis, M.; Glencross, A.; Sexton, A. Bringing cultured meat to market: Technical, socio-political, and regulatory challenges in cellular agriculture. Trends Food Sci. Technol. 2018, 78, 155-166. [CrossRef]

51. Ostrovidov, S.; Ahadian, S.; Ramon-Azcon, J.; Hosseini, V.; Fujie, T.; Parthiban, S.P.; Shiku, H.; Matsue, T.; Kaji, H.; Ramalingam, M.; et al. Three-dimensional co-culture of C2C12/PC12 cells improves skeletal muscle tissue formation and function. J. Tissue Eng. Regen. Med. 2017, 11, 582-595. [CrossRef]

52. Hosseini, V.; Ahadian, S.; Ostrovidov, S.; Camci-Unal, G.; Chen, S.; Kaji, H.; Ramalingam, M.; Khademhosseini, A. Engineered Contractile Skeletal Muscle Tissue on a Microgrooved Methacrylated Gelatin Substrate. Tissue Eng. Part A 2012, 18, 2453-2465. [CrossRef]

53. Noori, A.; Ashrafi, S.J.; Vaez-Ghaemi, R.; Hatamian-Zaremi, A.; Webster, T.J. A review of fibrin and fibrin composites for bone tissue engineering. Int. J. Nanomed. 2017, 12, 4937-4961. [CrossRef] [PubMed]

54. Rouwkema, J.; Koopman, B.; Blitterswijk, C.; Dhert, W.; Malda, J. Supply of nutrients to cells in engineered tissues. Biotechnol. Genet. Eng. Rev. 2010, 26, 163-178. [CrossRef] [PubMed]

55. Sarker, M.; Naghieh, S.; Sharma, N.; Chen, X. 3D biofabrication of vascular networks for tissue regeneration: A report on recent advances. J. Pharm. Anal. 2018, 8, 277-296. [CrossRef] [PubMed]

56. Anderson, J.E. A Role for Nitric Oxide in Muscle Repair: Nitric Oxide-mediated Activation of Muscle Satellite Cells. Mol. Biol. Cell 2000, 11, 1859-1874. [CrossRef] [PubMed]

57. Tengan, C.H.; Rodrigues, G.S.; Godinho, R.O. Nitric Oxide in Skeletal Muscle: Role on Mitochondrial Biogenesis and Function. Int. J. Mol. Sci. 2012, 13, 17160-17184. [CrossRef] [PubMed]

58. Schubert, D.; LaCorbiere, M. Altered collagen and glycosaminoglycan secretion by a skeletal muscle myoblast variant. J. Biol. Chem. 1980, 255, 11557-11563.

59. Gutierrez, J.; Osses, N.; Brandan, E. Changes in secreted and cell associated proteoglycan synthesis during conversion of myoblasts to osteoblasts in response to bone morphogenetic protein-2: Role of decorin in cell response to BMP-2. J. Cell Physiol. 2006, 206, 58-67. [CrossRef]

60. Brandan, E.; Fuentes, M.E.; Andrade, W. The proteoglycan decorin is synthesized and secreted by differentiated myotubes. Eur. J. Cell Biol. 1991, 55, 209-216.

61. Yam, K.L.; Papadakis, S.E. A simple digital imaging method for measuring and analyzing color of food surfaces. J. Food Eng. 2004, 61, 137-142. [CrossRef]

62. Holman, B.W.; Van De Ven, R.J.; Mao, Y.; Coombs, C.E.; Hopkins, D.L. Using instrumental (CIE and reflectance) measures to predict consumers' acceptance of beef colour. Meat Sci. 2017, 127, 57-62. [CrossRef]

63. Kaewthong, P.; Waiyagan, K.; Wattanachant, S. Imaging Analysis by Digital Camera for Separating Broiler Breast Meat with Low Water-Holding Capacity. J. Poult. Sci. 2017, 54, 253-261. [CrossRef]

64. Solli, M.; Andersson, M.; Lenz, R.; Kruse, B. Color Measurements with a Consumer Digital Camera Using Spectral Estimation Techniques; Springer Science and Business Media LLC: Berlin, Germany, 2005; Volume 3540, pp. 105-114.

65. De Souza, J.S.; Brunetto, E.L.; Nunes, M.T. Iron restriction increases myoglobin gene and protein expression in Soleus muscle of rats. An. Acad. Bras. Cienc. 2016, 88, 2277-2290. [CrossRef] [PubMed]

66. Schlater, A.E.; De Miranda, M.A.; Frye, M.A.; Trumble, S.J.; Kanatous, S.B. Changing the paradigm for myoglobin: A novel link between lipids and myoglobin. J. Appl. Physiol. 2014, 117, 307-315. [CrossRef] [PubMed]

67. Rayner, B.S.; Hua, S.; Sabaretnam, T.; Witting, P.K. Nitric oxide stimulates myoglobin gene and protein expression in vascular smooth muscle. Biochem. J. 2009, 423, 169-177. [CrossRef] [PubMed]

68. Maruta, H.; Yoshimura, Y.; Araki, A.; Kimoto, M.; Takahashi, Y.; Yamashita, H. Activation of AMP-Activated Protein Kinase and Stimulation of Energy Metabolism by Acetic Acid in L6 Myotube Cells. PLoS ONE 2016, 11, e0158055. [CrossRef] [PubMed] 
69. Bakhtiari, N.; Hosseinkhani, S.; Soleimani, M.; Hemmati, R.; Noori-Zadeh, A.; Javan, M.; Tashakor, A. Short-term ursolic acid promotes skeletal muscle rejuvenation through enhancing of SIRT1 expression and satellite cells proliferation. Biomed. Pharmacother. 2016, 78, 185-196. [CrossRef] [PubMed]

70. Hubbi, M.E.; Semenza, G.L. Regulation of cell proliferation by hypoxia-inducible factors. Am. J. Physiol. Physiol. 2015, 309, C775-C782. [CrossRef] 